in other parts of Africa. The conference also set up a panel to explore the practicability of publishing an international journal of African history.

It is intended that a full report of the proceedings of the conference shall be published as soon as possible.

$$
\text { [Communicated by D. H. Jones] }
$$

\title{
A Native Farming Settlement at Gandajika, Belgian Congo
}

EXPERIMENTs have been made in recent years to establish native farmers' settlements in the Belgian Congo, with a view to controlling the exodus of younger members of the population towards the towns, and increasing agricultural production by modern methods. The administration has allocated land on chosen sites, after investigating the customary rights to the soil, and farmers receiving land in this way have followed a predetermined programme of cultivation based on crop rotation.

Such a settlement has been in existence at Gandajika since 1947, and some 8,000 farmers are now cultivating allotments of 15 to 18 acres each. There is a rotation of food as well as of cash crops, which allows each field to temain fallow for six years. Administrative officers and the specialist staff of the local INEAC (National Institute for Agricultural Research) study together the problems of sharing out seed to the farmers and of finding the best and most economic fertilizers to suit local needs. The farmer pays a small tent for the use of tractors and other machines. Game is scarce in this region, and efforts have been made to augment the amount of protein in the diet by increasing the number of fish ponds; the district now has some 4,000 ponds, each yielding annually about $12 \mathrm{cwt}$. of fish per acre. Cattle farming, poultry, goat and sheep breeding, have also been started at Gandajika and there are two buying and selling co-operative societies whose thousands of members act as intermediaries for the farmers.

Stabilization of the population of the district of Gandajika has been achieved by this development. New methods have also improved the quality of the produce and thereby increased the farmers' income. The settlement of the population has brought about an increase in social benefits and the Native Welfare Fund has been able to build a modern hospital and dispensary, maternity homes, more durable houses, and a vocational establishment for the training of masons and carpenters. There is a branch of the National Savings Bank and social centres where assistants are being trained to look after women and children.

\section{International Institute of Differing Civilisations}

THE thirtieth study session of INCIDI was held in Lisbon from is to 18 April 1957, under the chairmanship of H.E. Commodore Sarmento Rodrigues, President of INCIDI, Member of the Portuguese National Assembly and formerly Minister for Overseas Affairs of Portugal. The subject of the session was 'Ethnic and cultural pluralism in intertropical societies', and twenty-nine working reports from many parts of Africa, South America, Indonesia, the British Caribbean, and Hong Kong were presented to the participants as a basis for discussion. The task of drawing up the conclusions of the discussions was entrusted to an Editorial Board, consisting of the four general rapporteurs, i.e. Professor Adriano Moreira (Portugal), Dr. P. J. Idenburg (Netherlands), Professor Gaston Leduc (France), and Professor Gilberto Freyre (Brazil).

As on former occasions, the working papers and the complete text of the discussions and conclusions will be published in book form. Meanwhile Vol. VII, No. 2 of the Institute's quarterly, Civilisations, contains a full report of conclusions reached by the conference with respect to the legal and political, social, and economic aspects of the factual situation, and the policies to be pursued in plural societies. 